\title{
A ABECO e o Código Florestal Brasileiro
}

\author{
Thomas Michael Lewinsohn*
}

\author{
${ }^{1}$ Departamento de Biologia Animal, Instituto de Biologia, \\ Universidade de Campinas - UNICAMP, Campinas, SP, Brasil
}

O lançamento da nova versão da Natureza \& Conservação está estreitamente vinculado a outro evento recente: o estabelecimento da ABECO, Associação Brasileira de Ciência Ecológica e Conservação, que assumiu este ano a responsabilidade desse periódico. Neste artigo, quero comentar algumas expectativas em relação a essa nova associação. Para isto, porém, devo tratar de um tema que se impôs em função de acontecimentos que marcam a política ambiental brasileira em 2010.

O Código Florestal Brasileiro (CFB) data de 1965 e continua em vigor, com importantes acréscimos e modificações em 1989 e 2001. Trata-se do principal marco legal ambiental para a ocupação e uso, produtivo ou não, do solo em propriedades privadas (há legislação específica para ordenamento das unidades de conservação). Apesar de existir há 45 anos, o CFB começou a chamar mais atenção há alguns anos, com a crescente atuação fiscalizadora e punitiva do IBAMA e de órgãos estaduais. Isto afeta propriedades rurais em todo o país: apesar do nome da lei, ela abrange também áreas originalmente de cerrado, campos e outras formações não-florestais. Além disto, a ocupação de áreas urbanas enquadradas como Áreas de Preservação Permanente no CFB, como topos de morro e áreas inundáveis, é passível de sanções judiciais.

O movimento para substituir o atual CFB começou a crescer fortemente em 2008. Em setembro de 2009, foi criada na Câmara dos Deputados uma Comissão Especial para delinear uma nova lei substitutiva ao atual Código (Brasil 2010). Em junho de 2010, em plena campanha presidencial e Copa do Mundo, o Deputado Aldo Rebelo apresentou seu relatório, em que encaminha proposta de nova lei (Rebelo 2010). Ainda em julho, sob pressão da bancada ruralista, lobistas e representantes de interesses, a Comissão Especial aprovou a proposta, encaminhando-a já para o plenário da Câmara. Seus proponentes insistem na extrema urgência em alterar o CFB, para debelar uma suposta crise na agricultura brasileira, incapaz de se expandir devido à atual legislação ambiental.

* Send correspondence to: Thomas Michael Lewinsohn. Departamento de Biologia Animal, Instituto de Biologia, Universidade de Campinas - UNICAMP, Campinas, SP, Brasil E-mail: thomasl@unicamp.br
Nas semanas que antecederam a publicação do Relatório Rabelo, cresceu também a movimentação contrária a ele, em forma de artigos assinados na grande imprensa, entrevistas, abaixo-assinados, e anúncios pagos. A maioria das alterações previstas na revisão do Código vem sendo contestada, tanto pelas ações que propõe, como pelas consequências que sua implementação trará. Estas últimas, em grande parte, são ignoradas pelo relator do projeto e pelas correntes que ele representa.

Não pretendo aqui tratar da reforma em si, nem suas ramificações, cujo alcance vai longe. Alguns desses aspectos são examinados por Metzger (2010), neste volume. A questão a discutir, aqui, é outra: como deve se posicionar uma sociedade científica sobre um problema claramente político, como o da reforma do CFB?

Há distintos caminhos que podem ser adotados (Wagner 1999). Uma associação científica pode optar por isentar-se completamente do debate político ou social, restringindo-se a mediar o acesso a informação técnica, se e quando solicitada. No outro extremo, pode engajar-se por completo, tomando partido dentro do debate. Condutas mais moderadas se situam entre tais polos.

A primeira opção tem sido defendida por quem entende que intrinsecamente o conhecimento científico é, ou deve ser, neutro - livre de valores morais. A ciência deve ser mantida à distância de polêmicas, para que os cientistas se façam ouvir e respeitar como detentores de um conhecimento técnico especializado. Dentro dessa ótica, a Sociedade para Avanço da Ciência americana propôs aos tribunais federais um projeto para indicar especialistas imparciais como consultores sobre assuntos controversos (Kaiser 1999).

Quando essa questão se centra em Ecologia, ela se torna mais complicada ainda do que em outras ciências (Wagner 1999). Seja por ignorância ou má fé, quando não por ambas, a ciência ecológica é geralmente des-entendida como uma forma de ativismo ambientalista. Críticos ou oponentes não reconhecem, assim, sua condição de conhecimento científico, e desqualificam qualquer manifestação de um ecólogo como uma posição certamente facciosa. 
No caso do Código Florestal, não há muito que hesitar. O atual projeto de reforma é nitidamente tendencioso e foi gestado sem a participação adequada de pesquisadores de áreas científicas cuja contribuição seria indispensável. Os defensores da proposta têm declarado que a comunidade científica foi ouvida mas, nos documentos da proposta e nas atas da Comissão Especial, percebe-se a incapacidade de reconhecer a autonomia da ciência ecológica, confundindo-a com organizações e atores ambientalistas.

Como presidente da ABECO, venho subscrevendo manifestações (e.g. Lewinsohn et al. 2010, Metzger \& Lewinsohn 2010, Metzger et al. 2010a,b) que reivindicam, antes de mais nada, que os cientistas - e não só eles - sejam adequadamente ouvidos e sua contribuição incorporada na produção de uma reforma responsável e consequente do Código Florestal. Este é um dos principais papéis que a ABECO deve exercer: representar, junto à opinião pública e seus formadores, e aos tomadores de decisão, políticos ou não, o conhecimento científico produzido pelos profissionais brasileiros do campo da ecologia. Essa representação, mesmo se não for neutra - dados os interesses em jogo - não pode ser facciosa, parcial, ou distorcida. Como uma sociedade científica que pretende ser ouvida e respeitada, a ABECO deve, antes de mais nada, expor de modo claro e correto o estado do conhecimento relevante a cada tema de interesse social e econômico: inclusive suas lacunas, inclusive também as divergências de julgamento entre especialistas (Mooney \& Ehrlich 1999).

Este papel é extenso demais para uma só pessoa ou diretoria. Para que possa ser bem desenvolvido, deve envolver contribuições de muitos associados que trabalham sobre aspectos relevantes a cada questão, e que se debruçam sobre elas há muitos anos. Além e antes disto, é fundamental que, tal como os fundadores dessa Associação, os profissionais que entendem a importância dos ecólogos serem representados perante a sociedade, se associem agora à ABECO. Há muitas outras atividades que a ABECO deve e pretende desenvolver - inclusive a publicação de periódicos como a nova Natureza \& Conservação - mas, hoje, a representação social do conhecimento ecológico talvez seja a mais premente.

\section{Agradecimentos}

Agradeço os comentários e sugestões de Rogério Parentoni Martins e Jean Paul Metzger.

\section{Referências}

Brasil, Câmara dos Deputados, 2010. Projeto de Lei PL-1876/1999. Disponível em: http://www.camara.gov.br/sileg/Prop_Detalhe. asp?id=17338. Acesso em: 4 jul. 2010.

Kaiser J, 1999. Expert testimony: project offers judges neutral science advice. Science 284: 1600a.

Lewinsohn TM et al., 2010. O tiro sai pela culatra. Folha de S. Paulo, 5 de Junho de 2010, p. A2.

Metzger JP, 2010. O Código Florestal tem base científica?. Natureza \& Conservação, 8:92-99.

Metzger JP \& Lewinsohn TM, 2010. Código do desflorestamento. O Estado de S. Paulo, 20 de Junho de 2010, p. J5.

Metzger JPM et al., 2010a. Devemos melhorar o código, não desfigurá-lo. O Estado de S. Paulo, 8 de Junho de 2010, p. A18.

Metzger JPM et al., 2010b. Brazilian environmental law - full speed in reverse?. Science. in press.

Mooney H \& Ehrlich P, 1999. Ecologists, advocacy and public policy [comentário a Wagner 1999]. Disponível em: http:// www.nceas.ucsb.edu/nceas-web/projects/resources/ecoessay/ wagner/rev1.html. Acesso em: 4 jul. 2010.

Rebelo A, 2010. Substitutivo ao Projeto de Lei 1876/99. Disponível em: http://www.camara.gov.br/sileg/Prop_Detalhe. asp?id=480244. Acesso em: 4 jul. 2010.

Wagner FH, 1999. Analysis and/or advocacy: what role(s) for ecologists? Santa Barbara, CA: NCEAS. [EcoEssay Series, 3.]. Disponível em: http://www.nceas.ucsb.edu/nceas-web/ projects/resources/ecoessay/wagner/

Recebido: Junho 2010

Primeira Decisão: Julho 2010

Aceito: Julho 2010 
